\title{
Napawanie krawędzi przedmiotów metodami TIG i PTA
}

\section{The surfacing of the items edges by TIG and PTA methods}

\section{Streszczenie}

W artykule przedstawiono badania zautomatyzowanego procesu napawania produkcyjnego i naprawczego krawędzi przedmiotów metodami TIG i PTA z materiałem dodatkowym w postaci zimnego drutu. Określono wpływ sposobu podawania drutu położenia jego końcówki względem jeziorka ciekłego metalu na stabilność procesu oraz kształt i jakość uzyskiwanych napoin. Zwrócono uwagę na zmienność warunków przebiegu procesu napawania przy zmianie stopnia koncentracji źródła ciepła. Wyznaczone pole parametrów optymalnych obu metod pozwoliło na opracowanie technologii napawania napoin o gładkim i równym licu na krawędziach przedmiotów oraz umożliwiło precyzyjne sterowanie kształtem i wymiarami geometrycznymi napoin.

\section{Wstęp}

Odpowiednie właściwości użytkowe warstwy wierzchniej przedmiotu, zarówno nowo wytwarzanego, jak remontowanego, można uzyskać przy zastosowaniu różnego rodzaju procesów technologicznych, do których należą m.in. procesy napawania. Zagadnienie napawania regeneracyjnego oraz produkcyjnego części maszyn jest również ważnym problemem technicznym i ekonomicznym przemysłu. Technologia napawania służy do przywrócenia pierwotnych właściwości warstwy wierzchniej regenerowanej części lub też nadania jej nowych lepszych właściwości eksploatacyjnych, co zapewnia nie-

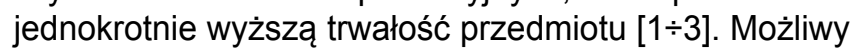
jest zatem dobór odpowiednich cech użytkowych części w zależności od potrzeb, uwzględniając przy tym istotne aspekty ekonomiczne. Koszty regeneracji starego

Dr inż. Tomasz Kik, dr inż. Jacek Górka, dr inż. Artur Czupryński, mgr inż. Adam Martyniszyn - Politechnika Śląska, Gliwice.

\section{Abstract}

The paper presents a test of automated manufacturing and repair surfacing by welding process of items edges. TIG and PTA with additional material in the form of a cold wire is used in the test. The influence of the method of wire supply and the wire tip position above the liquid metal on the process stability and also the shape and quality of padding welds are investigated. The variation of the process of surfacing in the change of concentration of the heat source is obtained. The designated field of optimal parameters of both methods led to the technology development of surfacing by welding which allows to produce high quality welds with a smooth and equal face on the edges of items and allowed to precise control of geometric shape and dimensions of padding welds.

elementu stanowią od kilku do kilkudziesięciu procent wartości elementu, natomiast trwałość takiego elemen-

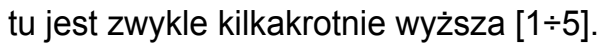

Jednym z najczęściej stosowanych obecnie spawalniczych sposobów naprawy zużytych elementów jest proces napawania regeneracyjnego metodą TIG. Początki tej metody sięgają lat 20. ub.w., kiedy w 1926 r. zostały zgłoszone przez Hobarta i Deversa patenty dotyczące spawania łukowego w osłonie helu oraz przez Weimmanna i Langmira dotyczące spawania dwoma elektrodami wolframowymi w osłonie wodoru. Dynamiczny rozwój spawania i napawania metodą TIG nastąpił w okresie drugiej wojny światowej, gdy metodę tę zaczęto stosować w przemyśle zbrojeniowym, szczególnie w lotnictwie. Obecnie metoda TIG jest jedną z podstawowych technologii spawalniczych stosowa-

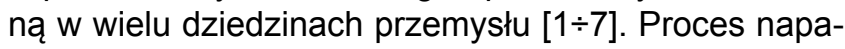
wania metodą TIG może być prowadzony na stanowiskach zautomatyzowanych lub zrobotyzowanych, dzięki czemu uzyskuje się, obok wysokiej czystości metalurgicznej, również dużą powtarzalność i precyzję wykonania napoin $[1,2]$. Dodatkowe zawężenie łuku 
w metodzie PTA powoduje z jednej strony znaczny wzrost efektywności nagrzewania powierzchni, a z drugiej - ograniczenie nagrzewanego obszaru [10].

Zastosowanie nowoczesnych metod regeneracji umożliwia uzyskanie wymiernych efektów ekonomicznych nie tylko wskutek naprawy zużytych części, ale również dzięki produkcji nowych.

\section{Stanowisko i materiały użyte do badań}

Celem badań było opracowanie techniki zrobotyzowanego napawania krawędzi przedmiotów metodą TIG oraz PTA z materiałem dodatkowym w postaci drutu proszkowego EnDOtec DO*13 o średnicy 1,2 mm na podłożu ze stali S355NL (tabl. I). Badania wykonano na zrobotyzowanym stanowisku badawczym składającym się z sześcioosiowego robota REIS SRV6, źródła prądu Eutronic GAP 2001DC oraz podajnika drutu zimnego KD3 firmy Castolin Eutectic (rys. 1).

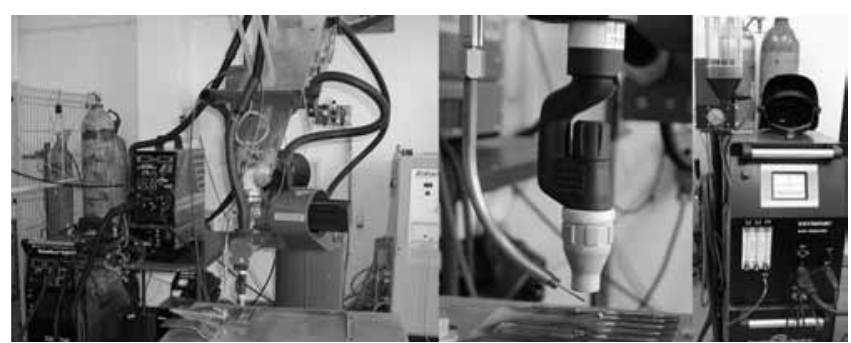

Rys. 1. Zrobotyzowane stanowisko do napawania metodami TIG i PTA Fig. 1. Automatic station for surfacing by TIG and PTA methods

\section{Wpływ kąta pochylenia palnika na kształt i jakość napoin}

Wstępne próby napawania wykazały, że wysoka jakość napoin w przypadku obu badanych metod można uzyskać przy ustawieniu punktu przecięcia się osi drutu i osi elektrod na powierzchni napawanego detalu (rys. 2). W celu określenia wpływu kąta pochylenia palnika względem napawanej powierzchni przeprowadzono próby napawania z odchyleniem palnika od pionu w zakresie $0 \div 45^{\circ}$ w osi poprzecznej do osi napoiny.

Tablica I. Skład chemiczny materiałów użytych do badań Table I. Chemical composition of tested materials

\begin{tabular}{|c|c|c|c|c|c|c|c|c|c|c|}
\hline \multicolumn{11}{|c|}{ Skład chemiczny stali S355NL, \% wag. } \\
\hline $\mathrm{C}$ & $\mathrm{Mn}$ & $\mathrm{Si}$ & $\mathrm{Cr}$ & $\mathrm{Ni}$ & $\mathrm{V}$ & $\mathrm{Cu}$ & $\mathrm{P}$ & $\mathrm{S}$ & $\mathrm{Al}$ & $\mathrm{N}$ \\
\hline $\max .0,2$ & $1 \div 1,5$ & $0,2 \div 0,55$ & $\max .0,30$ & $\max .0,03$ & $0,05 \div 0,15$ & $\max .0,30$ & $\max .0,04$ & $\max .0,035$ & $\min .0,02$ & $0,01 \div 0,025$ \\
\hline \multicolumn{11}{|c|}{ Skład chemiczny, stopiwa drutu EnDOtec DO 13, \% wag. } \\
\hline \multicolumn{2}{|c|}{ Rodzaj drutu } & C & \multicolumn{2}{|c|}{$\mathrm{Si}$} & $\mathrm{Mn}$ & \multicolumn{2}{|c|}{$\mathrm{P}$} & \multicolumn{2}{|l|}{ S } & $\mathrm{Cr}$ \\
\hline \multicolumn{2}{|c|}{ EnDOtec DO*13 } & 0,45 & \multicolumn{2}{|c|}{3,0} & 0,5 & \multicolumn{2}{|c|}{0,02} & \multicolumn{2}{|l|}{0,01} & 9,5 \\
\hline
\end{tabular}

Tablica II. Wpływ zmiany kąta pochylenia palnika na jakość napoin

Table II. The influence of the change of blowpipe angle on the quality of padding welds

\begin{tabular}{|c|c|c|c|c|c|c|c|c|}
\hline \multirow{2}{*}{ Kąt odchylenia palnika, ${ }^{\circ}$ * } & \multirow{2}{*}{ Ozn. próbki } & \multirow{2}{*}{$I, \mathrm{~A}$} & \multirow{2}{*}{$U, \mathrm{~V}$} & \multirow{2}{*}{$v_{\text {nap }}, \mathrm{mm} / \mathrm{s}$} & \multirow{2}{*}{$E, \mathrm{~J} / \mathrm{mm}$} & \multirow{2}{*}{$v_{d r}, \mathrm{~cm} / \mathrm{min}$} & \multicolumn{2}{|c|}{ Ocena jakości } \\
\hline & & & & & & & TIG & PTA \\
\hline \multirow{3}{*}{45} & TIG 45L & 90 & \multirow{2}{*}{10,5} & 2,0 & 472 & 50 & \multirow{2}{*}{ wysoka jakość } & \multirow{2}{*}{-} \\
\hline & TIG $45 \mathrm{H}$ & 110 & & 5,0 & 231 & 70 & & \\
\hline & PTA 45 & 50 & 24,3 & 4,0 & 303 & 60 & \multirow{2}{*}{-} & \multirow{2}{*}{ wysoka jakość } \\
\hline 40 & PTA 40 & 50 & 25 & 4,0 & 312 & 60 & & \\
\hline \multirow{3}{*}{30} & TIG 30L & 90 & \multirow{2}{*}{10,5} & 2,0 & 472 & 50 & \multirow{2}{*}{ wysoka jakość } & \multirow{2}{*}{-} \\
\hline & TIG $30 \mathrm{H}$ & 110 & & 5,0 & 231 & 70 & & \\
\hline & PTA 30 & 50 & 25 & 4,0 & 312 & 60 & - & wysoka jakość \\
\hline 25 & PTA 25 & 50 & 23,7 & 4,0 & 296 & 60 & - & wysoka jakość \\
\hline \multirow{2}{*}{15} & TIG 15H & 110 & 10,5 & 5,0 & 231 & 70 & wysoka jakość & - \\
\hline & PTA 15 & 50 & 23,7 & 4,0 & 296 & 60 & - & wysoka jakość \\
\hline \multirow{3}{*}{0} & TIG OL & 90 & \multirow{2}{*}{10,5} & 2,0 & 472 & 50 & \multirow{2}{*}{ wysoka jakość } & \multirow[b]{2}{*}{-} \\
\hline & TIG OH & 110 & & 5,0 & 231 & 100 & & \\
\hline & PTA 0 & 50 & 28,6 & 4,0 & 357 & 60 & - & wysoka jakość \\
\hline
\end{tabular}

UWAGI: Proces napawania TIG: napawanie prądem stałym DC(-), elektroda nietopliwa $\mathrm{W}+\mathrm{ThO}_{2} \mathrm{o}$ średnicy $1,6 \mathrm{~mm}$, kąt ostrzenia elektrody $-60^{\circ}$, odległość elektrody od materiału napawanego $-5 \mathrm{~mm}$, gaz ochronny - argon o natężeniu przepływu 12 $\mathrm{dm}^{3} / \mathrm{min}$, kąt pochylenia drutu względem napawanej krawędzi - $20^{\circ}$; przygotowanie krawędzi - krawędzie proste, kąt: $90^{\circ}$;

Proces napawania PTA: napawanie prądem stałym DC(-), elektroda nietopliwa $\mathrm{W}+\mathrm{ThO}_{2}$ o średnicy $1,6 \mathrm{~mm}$, kąt zaostrzenia elektrody $30^{\circ}$, średnica dyszy plazmowej - 1,7 mm, odległość dyszy od materiału napawanego - $4 \mathrm{~mm}$, gaz ochronny - argon o natężeniu przepływu $12 \mathrm{dm}^{3} / \mathrm{min}$, kąt pochylenia drutu względem napawanej krawędzi - $20^{\circ}$; przygotowanie krawędzi - krawędzie proste, kąt: $90^{\circ}$;

Materiał dodatkowy: drut proszkowy EnDOtec DO13 o średnicy $1,2 \mathrm{~mm}$.

Oznaczenia: * kąt odchylenia palnika od osi prostopadłej do płaszczyzny napawanej; $I$ - natężenie prądu, $U$ - napięcie łuku, $v_{\text {nap }}$ - prędkość napawania, $\mathrm{v}_{\mathrm{dr}}$ - prędkość podawania drutu, $E$ - energia liniowa procesu. 


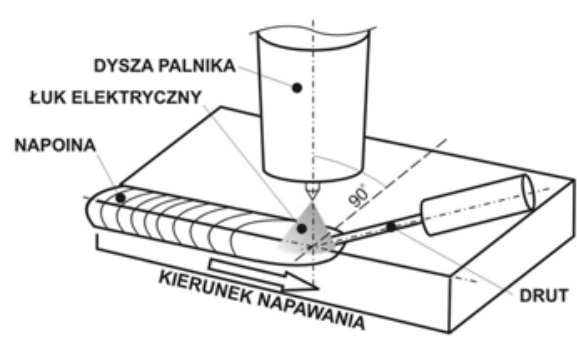

Rys. 2. Schemat procesu napawania TIG/PTA z materiałem dodatkowym w postaci drutu krawędzi przedmiotów

Fig. 2. The shame of the TIG/PTA surfacing of items edges with wire as filler material

Pozostałe parametry procesu utrzymywano w zakresie parametrów ustalonych podczas badań wstępnych zapewniających stabilne stapianie się drutu oraz uzyskanie gładkiego, równego lica napoiny. Ocenę jakości uzyskanych napoin przeprowadzono na podstawie badań wizualnych i makroskopowych (tabl. II).

\section{Wpływ techniki podawania drutu na kształt i jakość napoin}

W kolejnym etapie badań ustalono wpływ położenia punktu przecięcia się osi elektrody $z$ osią drutu względem napawanej krawędzi na jakość uzyskanych a)
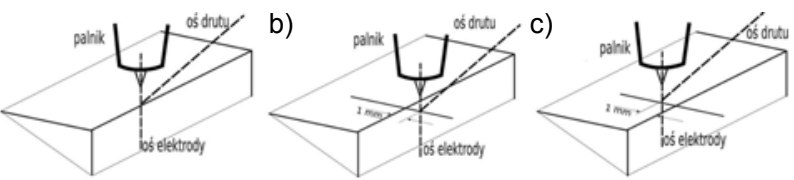

Rys. 3. Ustawienie punktu przecięcia osi drutu z osią elektrody względem napawanej krawędzi

Fig. 3. The position of the wire and electrode axis cross point relatively to the surfacing edge

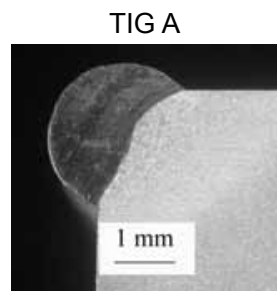

PTAA

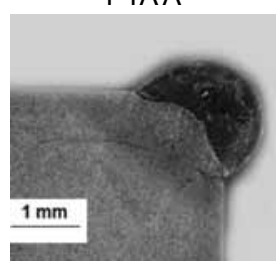

TIG B

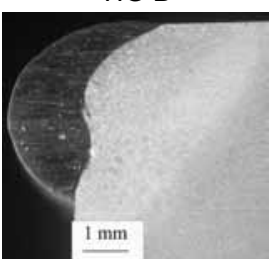

PTA B

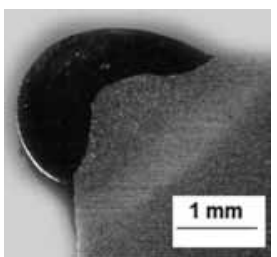

TIG C

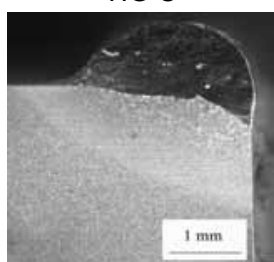

PTA C
Rys. 4. Makrostruktura napoin wykonanych metodami TIG i PTA przy różnym ustawieniu punktu przecięcia osi drutu z osią elektrody względem napawanej krawędzi (tabl. III)

Fig. 4. The macrostructure of the TIG and PTA padding welds in different position of the cross point of wire and electrode relatively to the edge (tab. III)

Tablica III. Wpływ zmian położenia palnika względem napawanej krawędzi (rys. 3 i 4 ) Table III. The change of orientation of blowpipe relatively to surfaced edge (fig. 3 and 4 )

\begin{tabular}{|c|c|c|c|c|c|c|c|c|}
\hline \multirow{2}{*}{$\begin{array}{l}\text { Ustawienie koń- } \\
\text { cówki palnika* }\end{array}$} & \multirow{2}{*}{$\begin{array}{l}\text { Ozn. } \\
\text { próbki }\end{array}$} & \multirow{2}{*}{$I, A$} & \multirow{2}{*}{$U, \mathrm{~V}$} & \multirow{2}{*}{$\begin{array}{l}v_{\text {nap }}, \\
\mathrm{mm} / \mathrm{s}\end{array}$} & \multirow{2}{*}{$E, \mathrm{~J} / \mathrm{mm}$} & \multirow{2}{*}{$\begin{array}{c}\mathrm{v}_{\mathrm{dr}}, \\
\mathrm{cm} / \mathrm{min}\end{array}$} & \multicolumn{2}{|c|}{ Ocena jakości } \\
\hline & & & & & & & TIG & PTA \\
\hline \multirow{2}{*}{ A } & TIG A & 110 & 10,5 & 3,0 & 385 & 70 & $\begin{array}{l}\text { wysoka jakość, (gładkie, rów- } \\
\text { ne lico napoiny, symetryczny } \\
\text { nadlew) }\end{array}$ & - \\
\hline & PTAA & 50 & 23,7 & 4,0 & 296 & 60 & - & $\begin{array}{l}\text { wysoka jakość, (gładkie, rów- } \\
\text { ne lico napoiny, symetryczny } \\
\text { nadlew) }\end{array}$ \\
\hline \multirow{2}{*}{ B } & TIG B & 110 & 10,5 & 3,0 & 385 & 70 & $\begin{array}{l}\text { niesymetryczny kształt napo- } \\
\text { iny (napoina na poziomej po- } \\
\text { wierzchni tworzącej krawędź) }\end{array}$ & - \\
\hline & PTA B & 50 & 22,3 & 3,0 & 371 & 60 & - & $\begin{array}{l}\text { wysoka jakość, (gładkie, rów- } \\
\text { ne lico napoiny, symetryczny } \\
\text { nadlew) }\end{array}$ \\
\hline \multirow[t]{2}{*}{$\mathrm{C}$} & TIG C & 110 & 10,5 & 3,0 & 385 & 70 & $\begin{array}{l}\text { niesymetryczny kształt na- } \\
\text { poiny, (napoina na pionowej } \\
\text { płaszczyźnie tworzącej kra- } \\
\text { wędź) }\end{array}$ & - \\
\hline & PTA C & 50 & 29,8 & 4,0 & 373 & 60 & - & nierówne lico \\
\hline
\end{tabular}

UWAGI: Proces napawania TIG: napawanie prądem stałym DC(-), elektroda nietopliwa $\mathrm{W}+\mathrm{ThO}_{2} \mathrm{o}$ średnicy $1,6 \mathrm{~mm}$, kąt ostrzenia elektrody $-60^{\circ}$, odległość elektrody od materiału napawanego $-5 \mathrm{~mm}$, gaz ochronny - argon o natężeniu przepływu 12 dm $3 /$ min, kąt pochylenia drutu względem napawanej krawędzi - $20^{\circ}$; przygotowanie krawędzi - krawędzie proste, kąt: $90^{\circ}$;

Proces napawania PTA: napawanie prądem stałym DC(-), elektroda nietopliwa $\mathrm{W}+\mathrm{Th} \mathrm{O}_{2}$ o średnicy $1,6 \mathrm{~mm}$, kąt zaostrzenia elektrody $30^{\circ}$, średnica dyszy plazmowej - 1,7 mm, odległość dyszy od materiału napawanego - $4 \mathrm{~mm}$, gaz ochronny - argon o natężeniu przepływu $12 \mathrm{dm}^{3} / \mathrm{min}$, gaz ochronny - argon o natężeniu przepływu $12 \mathrm{dm}^{3} / \mathrm{min}$, kąt pochylenia drutu względem napawanej krawędzi - $20^{\circ}$; przygotowanie krawędzi - krawędzie proste, kąt: $90^{\circ}$;

Materiał dodatkowy: drut proszkowy EnDOtec DO13 o średnicy 1,2 mm.

Oznaczenia: $I$ - natężenie prądu, $U$-napięcie łuku, $v_{n a p}$ - prędkość napawania, $v_{d r}$ - prędkość podawania drutu, $E$ - energia liniowa procesu; * - położenie punktu przecięcia się osi elektrody z osią drutu względem napawanej krawędzi wg rys. 3. 
napoin. W tym celu przeprowadzono próby napawania przy trzech ustawieniach:

- oś drutu przecina się z osią krawędzi (rys. 3a),

- oś drutu odsunięta jest od osi napawanej krawędzi o $1 \mathrm{~mm}$ w płaszczyźnie poziomej (rys. 3b),

- oś drutu przesunięta w kierunku poziomej płaszczyzny od krawędzi o $1 \mathrm{~mm}$ jest w płaszczyźnie poziomej (rys. 3c).

We wszystkich przypadkach oś elektrody leżała w jednej płaszczyźnie z osią drutu. Jakość uzyskanych napoin określono na podstawie badań wizualnych i makroskopowych (tab. III).

\section{Wpływ energii liniowej procesu napawania krawędzi na kształt i jakość napoin}

Określenie stabilnych warunków stapiania drutu oraz powstawania napoin krawędziowych pozwoliło na przeprowadzenie badań wpływu zmiany energii liniowej procesu na kształt i jakość napoin. Ocenę jakości uzyskanych napoin przeprowadzono na podstawie badań wizualnych i makroskopowych (tabl. IV). Określono również wpływ zmian energii liniowej na podstawowe wymiary napoin krawędziowych (tabl. V).

\section{Wpływ sposobu przygotowania krawędzi na kształt i jakość napoin}

Badania prowadzono na krawędziach ostrych, takich jak w przypadku napawania produkcyjnego nowych elementów. Ponieważ często zachodzi konieczność regeneracji zużytych bądź uszkodzonych części, przeprowadzono również próby napawania krawędzi frezowanych pod kątem $45^{\circ}$, tak aby uzyskać płaską powierzchnię o szerokości 1 i $2 \mathrm{~mm}$ (rys. 6). Parametry procesu utrzymywano w zakresie optymalny mustalonym na podstawie wcześniejszych badań (tabl. VI).

\section{Pomiary twardości napoin krawędziowych wykonanych metodami TIG i PTA}

W celu określenia wpływu cyklu cieplnego procesu napawania na twardość napoin oraz SWC przeprowadzono pomiar twardości przy stałym obciążeniu wynoszącym $200 \mathrm{~g}$ na trzech wybranych próbkach wykonanych przy niskiej, średniej i wysokiej energii liniowej wzdłuż linii pomiarowej prowadzącej od obszaru lica do materiału podłoża (tab. VII).
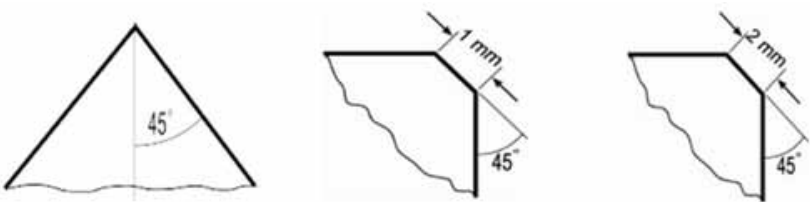

Rys. 6. Przygotowanie krawędzi do napawania (tabl. VI)

Fig. 6. Preparation of edges for surfacing (tabl. VI)
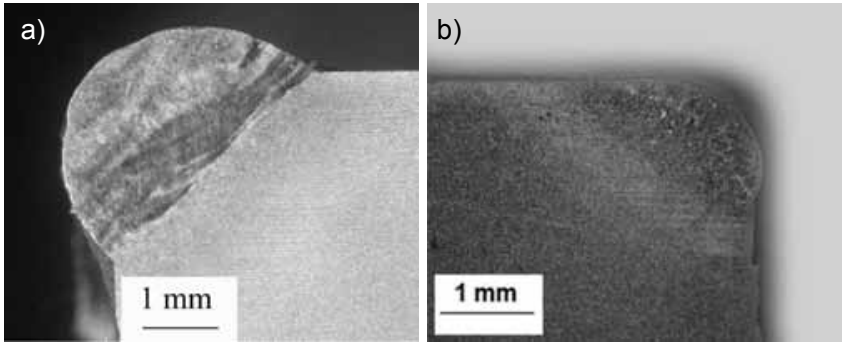

Rys. 7. Makrostruktury napoin wykonanych na krawędziach frezowanych $2 \times 45^{\circ}$ a) metodą TIG, b) metodą PTA (tabl. VI)

Fig. 7. The macrostructure of padding welds on the milled edges with the angle of $2 \times 45^{\circ}$, a) TIG method, b) PTA method (tab. IV)

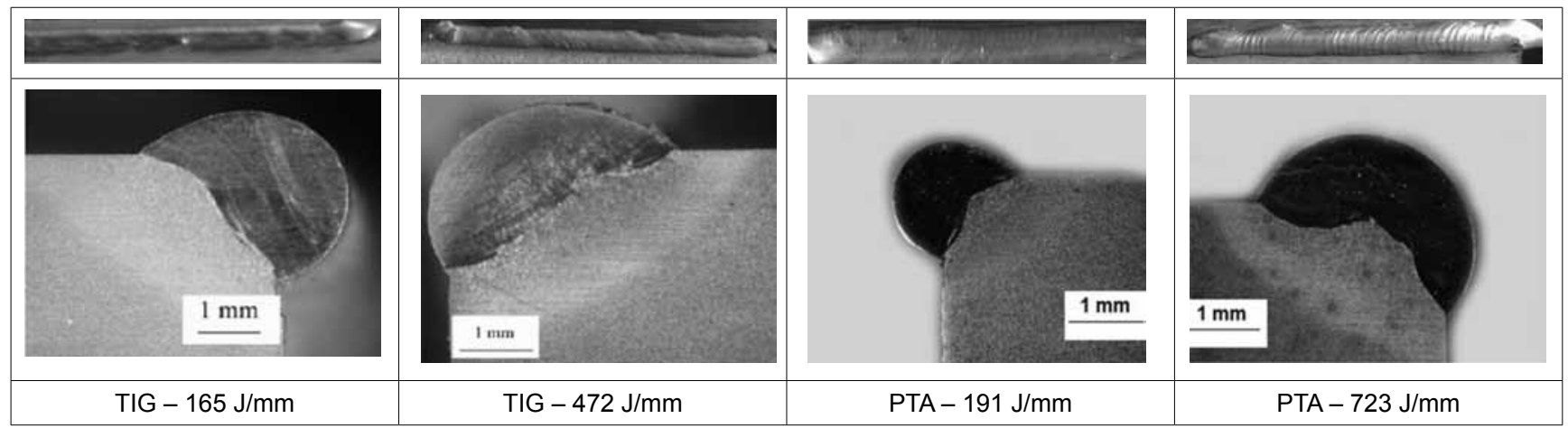

Rys. 5. Widok lica i makrostruktury napoin wykonanych metodami TIG i PTA przy niskiej i wysokiej energii liniowej, (tabl. IV i V)

Fig. 5. The view of the face and the macrostructure of the padding welds made with the low and high welding energy (tab. IV and $\mathrm{V}$ ) 
Tablica IV. Wpływ zmiany energii liniowej oraz prędkości podawania drutu na jakość i kształt napoin krawędziowych (rys. 5)

Table IV. The influence of welding energy and the wire supply speed change in the quality and shape of the edge padding welds (fig. 5)

\begin{tabular}{|c|c|c|c|c|c|c|c|c|c|c|c|}
\hline Ozn. napoiny & $I, A$ & $U, \mathrm{~V}$ & $v_{\text {nap }}, \mathrm{mm} / \mathrm{s}$ & $v_{d r}, \mathrm{~cm} / \mathrm{min}$ & $E, \mathrm{~J} / \mathrm{mm}$ & Ocena jakości & $B, \mathrm{~mm}$ & $H, \mathrm{~mm}$ & $B, \mathrm{~mm}$ & $h, \mathrm{~mm}$ & $U_{p}, \%$ \\
\hline \multicolumn{12}{|c|}{ kąt pochylenia palnika względem poziomej płaszczyzny tworzącej krawędź - 90 } \\
\hline TIG 1 & 90 & \multirow{5}{*}{10,5} & 2,0 & 50 & 472 & \multirow{5}{*}{$\begin{array}{l}\text { wysoka } \\
\text { jakość }\end{array}$} & 3,42 & 3,91 & 1,95 & 3,89 & 38,18 \\
\hline TIG 2 & \multirow{4}{*}{110} & & 3,0 & \multirow{2}{*}{70} & 385 & & 3,12 & 3,29 & 1,92 & 3,16 & 37,13 \\
\hline TIG 3 & & & 4,0 & & 288 & & 3,33 & 2,97 & 2,17 & 2,24 & 32,12 \\
\hline TIG 4 & & & 5,0 & \multirow{2}{*}{100} & 231 & & 3,93 & 4,08 & 2,31 & 3,87 & 35,77 \\
\hline TIG 5 & & & 7,0 & & 165 & & 2,03 & 2,05 & 1,38 & 1,58 & 34,38 \\
\hline \multicolumn{12}{|c|}{ kąt pochylenia palnika względem poziomej płaszczyzny tworzącej krawędź - $45^{\circ}$} \\
\hline TIG 6 & 90 & \multirow{4}{*}{10,5} & 2,0 & 50 & 472 & \multirow{3}{*}{$\begin{array}{l}\text { wysoka } \\
\text { jakość }\end{array}$} & 4,49 & 2,35 & 2,69 & 1,10 & 31,58 \\
\hline TIG 7 & \multirow{3}{*}{110} & & 3,0 & \multirow{3}{*}{70} & 385 & & 2,92 & 2,55 & 2,43 & 1,90 & 39,51 \\
\hline TIG 8 & & & 5,0 & & 231 & & 2,43 & 1,70 & 2,56 & 0,70 & 28,54 \\
\hline TIG 9 & & & 7,0 & & 165 & niesymetrycz- & 3,05 & 1,58 & 3,05 & 0,62 & 28,20 \\
\hline TIG 10 & 120 & 10,7 & 10,0 & 120 & 126 & napoiny & 2,45 & 1,68 & 2,37 & 0,66 & 27,76 \\
\hline
\end{tabular}

UWAGI: napawanie prądem stałym DC(-), elektroda nietopliwa $\mathrm{W}+\mathrm{ThO}_{2}$ o średnicy 1,6 mm, kąt ostrzenia elektrody - 60 ${ }^{\circ}$ odległość elektrody od materiału napawanego - 5,0 mm, gaz ochronny - argon o natężeniu przepływu $12 \mathrm{dm}^{3} / \mathrm{min}$, kąt pochylenia drutu względem napawanej krawędzi - $20^{\circ}$; przygotowanie krawędzi - krawędzie proste, kąt: $90^{\circ}$;

Oznaczenia: $I$ - prąd napawania, $U$ - napięcie łuku, $v_{n}$ - prędkość napawania, $v_{p}$ - prędkość podawania drutu, $E$ - energia liniowa, B - szerokość napoiny $\mathrm{mm}, H$ - wysokość napoiny $\mathrm{mm}, b$ - szerokość wtopienia napoiny w płaszczyznę poziomą mm, $h$ - wysokość wtopienia napoiny w płaszczyznę pionową $\mathrm{mm}, U_{p}-$ udział metalu podłoża w napoinie $U_{s}=\frac{P_{v}}{P_{p} P_{x}}$ ano gdzie: $P_{w}-$ pole powierzchni wtopienia, Pn - pole napoiny

Tablica V. Wpływ zmian energii liniowej oraz prędkości podawania drutu na jakość i kształt napoin krawędziowych (rys. 5)

Table V. The influence of welding energy and the wire supply speed change in the quality and shape of the edge padding welds (fig. 5)

\begin{tabular}{|c|c|c|c|c|c|c|c|c|c|c|c|}
\hline Ozn. napoiny & I, A & $U, \mathrm{~V}$ & $v_{n}, \mathrm{~mm} / \mathrm{s}$ & $v_{p}, \mathrm{~mm} / \mathrm{s}$ & $E, \mathrm{~kJ} / \mathrm{mm}$ & Ocena jakości & $B, \mathrm{~mm}$ & $H, \mathrm{~mm}$ & $b, \mathrm{~mm}$ & $h, \mathrm{~mm}$ & $U_{s}, \%$ \\
\hline PTA 1 & 30 & 25,5 & 4,0 & 40 & 191 & wysoka jakość & 1,67 & 1,63 & 0,75 & 1,29 & 10,52 \\
\hline PTA 2 & \multirow{2}{*}{35} & 15,5 & 1,0 & 35 & 543 & nierównomierne lico & 4,51 & 3,20 & 3,21 & 2,24 & 10,64 \\
\hline PTA 3 & & 25,5 & 4,0 & 40 & 223 & niesymetryczny nadlew & 1,98 & 2,62 & 0,86 & 2,15 & 11,42 \\
\hline PTA 4 & \multirow{3}{*}{40} & 24,5 & 1,6 & \multirow{4}{*}{40} & 613 & nierównomierne lico & 3,33 & 3,79 & 2,56 & 3,60 & 15,03 \\
\hline PTA 5 & & 25,5 & 4,0 & & 255 & niesymetryczny nadlew & 1,64 & 2,49 & 0,94 & 2,47 & 12,01 \\
\hline PTA 6 & & 25,5 & 5,0 & & 204 & wysoka jakość & 2,17 & 2,15 & 1,70 & 1,74 & 15,06 \\
\hline PTA 7 & 50 & 21,4 & 1,5 & & 713 & \multirow{3}{*}{ nierównomierne lico } & 4,14 & 3,14 & 3,06 & 1,76 & 12,77 \\
\hline PTA 8 & \multirow{7}{*}{50} & 16,2 & 1,4 & \multirow{3}{*}{60} & 579 & & 4,16 & 3,06 & 2,58 & 1,98 & 34,53 \\
\hline PTA 9 & & 16,6 & 1,8 & & 461 & & 4,27 & 3,40 & 2,21 & 3,06 & 13,80 \\
\hline PTA 10 & & 28,9 & 2,0 & & 723 & \multirow{10}{*}{ wysoka jakość } & 4,05 & 3,21 & 1,98 & 1,53 & 15,83 \\
\hline PTA 11 & & 18,3 & 3,0 & \multirow{4}{*}{70} & 305 & & 2,82 & 2,26 & 2,05 & 1,40 & 20,32 \\
\hline PTA 12 & & 22,3 & 3,5 & & 319 & & 2,66 & 2,35 & 1,61 & 1,72 & 25,14 \\
\hline PTA 13 & & 24,2 & 4,0 & & 303 & & 2,26 & 2,28 & 1,29 & 1,82 & 24,91 \\
\hline PTA 14 & & 24,7 & 5,0 & & 247 & & 2,89 & 2,56 & 2,02 & 1,89 & 30,69 \\
\hline PTA 15 & 55 & 20,4 & 2,0 & 50 & 561 & & 3,36 & 3,11 & 1,62 & 2,88 & 18,22 \\
\hline PTA 16 & 65 & 20,4 & \multirow{2}{*}{4,0} & \multirow{2}{*}{70} & 332 & & 3,21 & 3,16 & 2,22 & 3,08 & 26,73 \\
\hline PTA 17 & 70 & 18,0 & & & 315 & & 3,29 & 3,28 & 2,14 & 3,00 & 33,07 \\
\hline PTA 18 & 80 & 17,0 & \multirow{2}{*}{5,0} & \multirow{2}{*}{90} & 272 & & 3,94 & 1,67 & 3,94 & 0,64 & 21,58 \\
\hline PTA 19 & 85 & 18,8 & & & 320 & & 2,05 & 2,94 & 2,31 & 2,94 & 30,44 \\
\hline
\end{tabular}

UWAGI: napawanie prądem stałym $\mathrm{DC}(-)$, elektroda nietopliwa $\mathrm{W}+\mathrm{ThO}_{2}$ o średnicy $1,6 \mathrm{~mm}$, kąt zaostrzenia elektrody $30^{\circ}$, średnica dyszy plazmowej - 1,7 mm, odległość dyszy od materiału napawanego - $4 \mathrm{~mm}$, gaz ochronny - argon o natężeniu przepływu 12 $\mathrm{dm}^{3} / \mathrm{min}$, kąt pochylenia drutu względem napawanej krawędzi - 20; przygotowanie krawędzi - krawędzie proste, kąt: $90^{\circ}$;

Oznaczenia: I - prąd napawania; $U$ - napięcie łuku; $v_{n}$ - prędkość napawania; $v_{p}$ - prędkość podawania drutu; $E$ - energia liniowa; $B$ - szerokość napoiny $\mathrm{mm}, H$ - wysokość napoiny $\mathrm{mm}, b$ - szerokość wtopienia napoiny w płaszczyznę poziomą mm, $\mathrm{h}$ - wysokość wtopienia napoiny w płaszczyznę pionową $\mathrm{mm}, U_{p}-$ udział metalu podłoża w napoinie 
Tablica VI. Wpływ sposobu przygotowania krawędzi do napawania na jakość napoin krawędziowych oraz udział materiału podłoża w napoinie (rys. 6 i 7 )

Table VI. The influence of edges preparation for surfacing on the edge padding weld quality and the mass fraction of base material in the padding weld (Fig. 6 and 7)

\begin{tabular}{|c|c|c|c|c|c|c|c|}
\hline Ozn. napoiny & I, A & $U, \mathrm{~V}$ & $v_{\text {nap }}, \mathrm{mm} / \mathrm{s}$ & $v_{d r}, \mathrm{~cm} / \mathrm{min}$ & $E, \mathrm{~J} / \mathrm{mm}$ & Ocena jakości & $U_{p}, \%$ \\
\hline \multicolumn{8}{|c|}{ sposób przygotowania krawędzi - 1x45 } \\
\hline TIG IV/1 & \multirow{2}{*}{90} & \multirow{4}{*}{10,5} & 2,0 & \multirow{2}{*}{50} & 472 & wysoka jakość & 40,17 \\
\hline TIG IV/2 & & & 4,0 & & 236 & niesymetryczny kształt napoiny & 36,33 \\
\hline TIG IV/3 & \multirow{2}{*}{110} & & 3,0 & \multirow{2}{*}{70} & 385 & \multirow{2}{*}{ wysoka jakość } & 38,38 \\
\hline TIG IV/4 & & & 5,0 & & 231 & & 39,65 \\
\hline PTA IV/1 & \multirow{4}{*}{50} & 25,6 & 4,0 & \multirow{4}{*}{50} & 320 & \multirow{4}{*}{ wysoka jakość } & 19,75 \\
\hline PTA IV/2 & & 25,4 & \multirow{3}{*}{5,0} & & 254 & & 25,14 \\
\hline PTA IV/3 & & 19,2 & & & 192 & & 23,90 \\
\hline PTA IV/4 & & 24,1 & & & 241 & & 25,91 \\
\hline \multicolumn{8}{|c|}{ sposób przygotowania krawędzi - 2x45 } \\
\hline TIG IV/5 & \multirow{2}{*}{90} & \multirow{4}{*}{10,5} & 2,0 & \multirow{2}{*}{50} & 472 & \multirow{4}{*}{ wysoka jakość } & 38,20 \\
\hline TIG IV/6 & & & 4,0 & & 236 & & 38,77 \\
\hline TIG IV/7 & \multirow{2}{*}{110} & & 3,0 & 70 & 385 & & 36,76 \\
\hline TIG IV/8 & & & 5,0 & \multirow{4}{*}{50} & 231 & & 37,21 \\
\hline PTA IV/5 & \multirow{3}{*}{50} & 24,3 & 10 & & 303 & & 23,89 \\
\hline PTA IV/6 & & 29,9 & 4,0 & & 373 & niska jakość, nierównomierne lico & 23,00 \\
\hline PTA IV/7 & & 24,6 & 3,0 & & 410 & & 31,58 \\
\hline \multicolumn{8}{|c|}{$\begin{array}{l}\text { UWAGI: Proces napawania TIG: napawanie prądem stałym } \mathrm{DC}(-) \text {, elektroda nietopliwa } \mathrm{W}+\mathrm{ThO} \mathrm{O}_{2} \text { o średnicy } 1,6 \mathrm{~mm} \text {, } \\
\text { kąt ostrzenia elektrody }-60^{\circ} \text {, odległość elektrody od materiału napawanego }-5 \mathrm{~mm} \text {, gaz ochronny - argon o natężeniu przepływu } 12,0 \\
\mathrm{dm}^{3} / \mathrm{min} \text {, kąt pochylenia drutu względem napawanej krawędzi }-20^{\circ} \text {; } \\
\text { Proces napawania } P T A \text { : napawanie prądem stałym } \mathrm{DC}(-) \text {, elektroda nietopliwa } \mathrm{W}+\mathrm{ThO}_{2} \text { o średnicy } 1,6 \mathrm{~mm} \text {, kąt zaostrzenia elektrody } 30^{\circ} \text {, } \\
\text { średnica dyszy plazmowej }-1,7 \mathrm{~mm} \text {, odległość dyszy od materiału napawanego }-4 \mathrm{~mm} \text {, gaz ochronny - argon o natężeniu przepływu } \\
12 \mathrm{dm}^{3} / \mathrm{min} \text {, kąt pochylenia drutu względem napawanej krawędzi }-20^{\circ} ; \\
\text { Oznaczenia: } I-\text { natężenie prądu, } U \text { - napięcie łuku, } v_{\text {nap }} \text { - prędkość napawania, } v_{d r}-\text { prędkość podawania drutu, E - energia liniowa pro- } \\
\text { cesu, } U_{p} \text { - udział metalu podłoża w napoinie. }\end{array}$} \\
\hline
\end{tabular}

Tablica VII. Wyniki pomiarów mikrotwardości HV0,2 na przekroju poprzecznym napoin krawędziowych

Table VII. The results of HV0.2 microhardness tests on the cross-sections of edge padding welds

\begin{tabular}{|c|c|c|c|c|c|c|c|}
\hline \multirow{3}{*}{\multicolumn{2}{|c|}{$\begin{array}{c}\text { Nr punktu } \\
\text { pomiarowego* }\end{array}$}} & \multicolumn{6}{|c|}{ Twardość HV0,2 } \\
\hline & & \multicolumn{3}{|c|}{ TIG } & \multicolumn{3}{|c|}{ PTA } \\
\hline & & $\begin{array}{l}\text { Min. energia li- } \\
\text { niowa }-165 \\
\mathrm{~J} / \mathrm{mm}\end{array}$ & $\begin{array}{c}\text { Śr. energia } \\
\text { liniowa }-231 \\
\mathrm{~J} / \mathrm{mm}\end{array}$ & $\begin{array}{c}\text { Max. energia li- } \\
\text { niowa }-472 \\
\mathrm{~J} / \mathrm{mm}\end{array}$ & $\begin{array}{l}\text { Min. energia li- } \\
\text { niowa - } 191 \\
\mathrm{~J} / \mathrm{mm}\end{array}$ & $\begin{array}{c}\text { Śr. energia } \\
\text { liniowa }-345 \\
\mathrm{~J} / \mathrm{mm}\end{array}$ & $\begin{array}{c}\text { Max. energia li- } \\
\text { niowa }-561[\mathrm{~J} / \\
\mathrm{mm}\end{array}$ \\
\hline \multirow{4}{*}{ Napoina } & 1 & 630,2 & 600,1 & 508,4 & 732,6 & 796,3 & 677 \\
\hline & 2 & 655,3 & 579,4 & 511,0 & 736,3 & 672,1 & 615,3 \\
\hline & 3 & 590,6 & 545,7 & 540,3 & 740 & 655,5 & 553,1 \\
\hline & 4 & 615,9 & 535,8 & 555,5 & 582 & 631,2 & 523,6 \\
\hline \multirow{2}{*}{ LW } & 5 & 624,5 & 579,0 & 544,4 & 630 & 560,5 & 546,5 \\
\hline & 6 & 645,5 & 584,0 & 520,2 & 554,9 & 440,3 & 427,4 \\
\hline \multirow{4}{*}{ SWC } & 7 & 480,6 & 440,1 & 349,0 & 404,2 & 358,3 & 420,1 \\
\hline & 8 & 423,3 & 429,1 & 404,0 & 409,5 & 374,2 & 404,2 \\
\hline & 9 & 444,1 & 445,0 & 370,2 & 319,2 & 382,8 & 383,8 \\
\hline & 10 & 407,2 & 408,8 & 263,3 & 221,4 & 371,6 & 347,3 \\
\hline \multirow{4}{*}{ MR } & 11 & 384,4 & 300,7 & 225,2 & 283 & 369,2 & 320,9 \\
\hline & 12 & 312,9 & 256,4 & 237,5 & 299,1 & 297,2 & 299,3 \\
\hline & 13 & 207,2 & 220,5 & 242,8 & 278,8 & 256,7 & 259,5 \\
\hline & 14 & 230,0 & 222,8 & 231,2 & 253,2 & 219,7 & 224,9 \\
\hline
\end{tabular}




\section{Podsumowanie}

Badania procesu zrobotyzowanego napawania TIG i PTA z materiałem dodatkowym w postaci drutu proszkowego EnDOtec D013 wykazały, że można uzyskać wysoką jakość napoin na krawędziach przedmiotów. Konieczne jest jednak ścisłe kontrolowanie wszystkich parametrów procesu, a szczególnie ustawienia palnika i końcówki układu podawania drutu względem napawanej krawędzi. Zastosowanie robota spawalniczego dodatkowo rozszerza zakres możliwości o precyzyjne napawanie krawędzi będących wycinkiem krzywej.

Badania wpływu kąta pochylenia palnika względem napawanej powierzchni na kształt i jakość napoin krawędziowych nie wykazały znaczącego wpływu na jakość otrzymanych napoin w przypadku napawania zarówno metodą TIG, jak i PTA. Przeprowadzone badania wpływu kąta pochylenia palnika względem poziomej płaszczyzny tworzącej napawaną krawędź na kształt i jakość napoin krawędziowych wykazały, że w całym badanym zakresie kątów pochylenia palnika istnieje możliwość uzyskania wysokiej jakości napoin (tabl. II). Na tej podstawie jako optymalną pozycję palnika określono przypadek, w którym jest on ustawiony prostopadle do poziomej powierzchni tworzącej napawaną krawędź. W przypadku zastosowania stanowisk zautomatyzowanych, a nie jak w badanym przypadku zrobotyzowanych, zwalnia to od konieczności dodatkowego pozycjonowania elementu, co znacznie skraca czas operacji.

Badania wpływu techniki podawania drutu do jeziorka ciekłego metalu wykazały, że odpowiednie ustawienie punktu przecięcia się osi drutu $z$ osią elektrody nietopliwej znacząco wpływa na sposób stapiania się drutu oraz stabilność prowadzenia procesu napawania. Ustawienie punktu przecięcia się osi drutu z osią elektrody dokładnie na krawędzi przedmiotu powoduje, że otrzymana napoina charakteryzuje się gładkim i równym licem (rys. 3a). Przesunięcie tego punktu na powierzchnię poziomą tworzącą napawaną krawędź powoduje uzyskanie napoiny o niesymetrycznym kształcie nadlewu, umieszczonej w przeważającej części na poziomej powierzchni tworzącej napawaną krawędź (rys. 3c i 4). Odsunięcie tego punktu w kierunku od napawanej krawędzi powoduje w przypadku napawania metodą TIG otrzymanie napoiny o nierównomiernym licu i niesymetrycznym kształcie nadlewu (tabl. III, rys. 3b i 4). Dodatkowo należy zauważyć, że w przypadku metody PTA odsunięcie punktu przecięcia osi drutu z osią elektrody w kierunku od napawanej krawędzi, pozwoliło na uzyskanie napoiny o wysokiej jakości (tabl. III, rys. 4). Ustawienie takie jednakże znacznie obniża stabilność jarzenia się łuku elektrycznego, prowadząc do niebezpieczeństwa obniżenia jakości napoin.
Opracowanie optymalnej techniki podawania materiału dodatkowego pozwoliło na przeprowadzenie badań wpływu zmian natężenia prądu, prędkości podawania drutu oraz prędkości napawania na kształt i jakość uzyskanych napoin. W przypadku napawania metodą TIG zmiana energii liniowej w zakresie od $165,0 \div 472,5 \mathrm{~J} / \mathrm{mm}$ pozwala na uzyskanie napoin o szerokości $2,4 \div 4,5 \mathrm{~mm}$ i wysokości $1,7 \div 4,1 \mathrm{~mm}$. Po procesie obróbki krawędzi szerokość warstwy napawanej zawiera się w zakresie 1,9 $\div 2,7 \mathrm{~mm}$ a wysokość $0,7 \div 3,9 \mathrm{~mm}$ (tabl. 4, rys. 5). Udział materiału podłoża w napoinach waha się w granicach $28 \div 40 \%$ i nieznacznie zależy od zmian energii liniowej w badanym zakresie. Przy minimalnej energii rzędu $156,0 \mathrm{~J} / \mathrm{mm}$ wynosi on ok. $28,5 \%$ i rośnie wraz ze wzrostem energii liniowej.

W przypadku metody PTA, zmiana energii liniowej w zakresie 191,0 $\div 723,0 \mathrm{~J} / \mathrm{mm}$ umożliwia uzyskanie napoin o szerokości $1,6 \div 4,0 \mathrm{~mm}$ i wysoko-

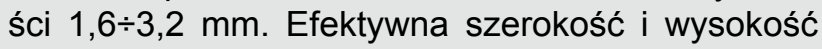
po procesie obróbki krawędzi zawiera się w zakresie odpowiednio: $0,75 \div 3,2 \mathrm{~mm}$ oraz $0,6 \div 3,0 \mathrm{~mm}$ (tabl. 4 , rys. 5). Udział materiału podłoża w napoinach jest znacznie mniejszy niż w przypadku napawania metodą TIG i wynosi $10 \div 30 \%$, rosnąc wraz ze wzrostem natężenia prądu (tabl. V). W metodzie PTA znacznie wyraźniej widać wpływ zawężenia łuku elektrycznego i co za tym idzie ścisłego powiązania stabilności procesu z pozostałym parametrami. W zakresie średnich $i$ wysokich energii liniowych udział materiału podłoża wynosi $10 \div 16 \%$. Zmniejszanie energii liniowej powoduje wzrost udziału materiału podłoża w napoinie nawet do ok. $33 \%$, przy energiach poniżej $300 \mathrm{~J} / \mathrm{mm}$. Spowodowane jest to tym, że wraz ze wzrostem natężenia prądu oraz spadkiem prędkości napawania rośnie ilość materiału dodatkowego stapiającego się na jednostkę długości. Konieczne jest więc zwiększenie prędkości podawania drutu. W przeciwnym przypadku, przy zbyt niskiej prędkości podawania drutu, gwałtownie rośnie wymieszanie materiału napoiny z materiałem podłoża i następuje silne nadtopienie napawanej krawędzi. Zbyt duża prędkość podawania drutu powoduje, niecałkowite jego stapianie i uzyskana napoina charakteryzuje się nierównym licem, a w skrajnych przypadkach przyklejonymi do krawędzi niestopionymi kawałkami drutu.

Badania wpływu przygotowania krawędzi do napawania, wykazały, że w przypadku napawania krawędzi frezowanych pod kątem $1 \times 45^{\circ}$ i $2 \times 45^{\circ}$ do płaszczyzny powierzchni poziomej tworzącej krawędź, znacznie trudniejsze jest uzyskanie wysokiej jakości napoin, a samo frezowanie krawędzi nie zmniejsza znacząco udziału materiału podłoża w napoinie (tabl. VI, rys. 6). Wcześniejsze przygotowanie krawędzi mające na celu zmniej- 
szenie udziału materiału podłoża w napoinie w przypadku metody napawania PTA, spowodowało znaczny spadek jakości uzyskanych napoin krawędziowych wynikający ze zbyt dużego zawężenia łuku i braku możliwości przetopienia całej szerokości przygotowanej powierzchni (rys. 8). Sytuacja taka może mieć istotne znaczenie przy procesie regeneracji uszkodzonej krawędzi, gdy wystąpi konieczność jej przygotowania przed procesem napawania. Rozwiązaniem w takim przypadku jest zastosowanie wyższych zakresów energii liniowej procesu napawania.

Pomiary twardości napoin wykonanych przy minimalnej, średniej i maksymalnej energii liniowej wykazały, że wraz ze wzrostem energii liniowej procesu ma- leje twardość napoin. Maksymalną twardość napoin ok. $630 \div 650$ HV0,2 uzyskano przy minimalnej energii liniowej wynoszącej 156,0 J/mm (tabl. VII). W przypadku napawania metodą PTA, wspomniana już wcześniej zależność udziału materiału podłoża w napoinie powoduje, że najwyższą twardość ok. 796 HV0,2 uzyskano w zakresie średnich energii liniowych - ok. $345 \mathrm{~J} / \mathrm{mm}$.

Przeprowadzone próby napawania krawędzi wykazały, że istnieje możliwość precyzyjnej naprawy oraz odtworzenia kształtów narzędzi i przedmiotów użytkowych. Szczególną uwagę należy zwrócić na konieczność zapewnienia wysokiej precyzji pozycjonowania końcówki drutu względem osi elektrody nietopliwej oraz napawanej krawędzi.

\section{Literatura}

[1] Zheng S., Dayou P., Min K.: Precision Welding for Edge Buildup and Rapid Prototyping, SIMTech Technical Report PT 00/001/JT, s. $1-7$.

[2] Cheng F.T., Lo K.H., Mana H.C.: NiTi cladding on stainless steel by TIG surfacing process Part II. Corrosion behavior, Surface \& Coatings Technology 172, 2003, s. 316-321.

[3] Song J., Deng Q., Chen Ch., Hu D., Li Y.. Rebuilding of metal components with laser cladding forming, Applied Surface Science 252, 2006.

[4] Shacklock A., Hong L., Sheng H., Wang Jie Yu J.: Intelligent Robotics GTAW System for 3D Welding, SIMTech Technical Report AT 01/013/AMP, s. 1-10.

[5] Kirkhope K.J., Bell R., Caron L., Basu R.I., Ma K.T.: Weld detail fatigue life improvement techniques. Part 2: application to ship structures, Marine Structures, vol. 12, issues 7-8, August 1999, s. 477-496.

[6] Gandy D.W., Frederick G., Stover J.T., Viswanathan R.: Overview of Hot Section Component Repair Methods. EPRI

RRAC Charlotte, North Carolina.

[7] F.T. Cheng, K.H. Lo, H.C. Mana: „NiTi cladding on stainless steel by TIG surfacing process Part I. Cavitation erosion behavior", Surface \& Coatings Technology 172 2003, s. 308315.

[8] Okazaki M., Ohetera I., Harada Y.: Damage Repair in CMSX4 Alloy without Fatigue Life Reduction Penalty. Metallurgical and Materials Transactions A. 2004, vol. 35. no. 2. s. 535-542.

[9] Zheng Sun, Min Kuo, Dayou: Twin wire Gas Tungsten Arc Cladding, SIMTech Technical Report PT 00/004/JT, s. 1-8.

[10] Bolmsjo G.: Programming robot welding system using advanced simulation tools, Division of Robotics, Dept. of Mechanical Engineering, Lund University, s. 1-8.

[11] Shu-Yi T., Ming-Der J., Wang J.T., Chun-Sen W.: A robots design in hardfacing using a plasma transfer arc, The International Journal of Advanced Manufacturing Technology, 2006, nr 9-10 vol. 27 , s. $889-896$.

\section{Polskie Towarzystwo Badań Nieniszczących i Diagnostyki Technicznej SIMP i} Stowarzyszenie Inżynierów i Techników Mechaników Polskich

\section{Krajowej Konferencji Badań Nieniszczących} w Warszawie, 24-26 października 2011 r. w Centrum Konferencyjno-Szkoleniowym „BOSS”

Biuro konferencji:

SIMP Ośrodek Doskonalenia Kadr w Warszawie

ul. Świętokrzyska 14A, 00-050 Warszawa

tel.: +48 2283901 51, fax: +48 228690786

e-mail: sekretariat@simp.odk.waw.pl

Strona internetowa konferencji: www.kkbn.pl

\section{Patronat:}

Ministerstwo Nauki I Szkolnictwa Wyższego

Prezes Urzędu Dozoru Technicznego

Patron medialny:

Przegląd Spawalnictwa, Przegląd Techniczny, Mechanik, Przegląd Mechaniczny 